\title{
Cultural Affiliation and Identity Constructs Under the British Mandate for Palestine
}

\author{
Tamara van Kessel
}

The British Mandate for Palestine was no mere temporary stewardship of the territories in question. Deploying Western scientific knowledge to map, mine and manage the area, "Britain entered the Mandate with grand ambitions to transform the territory in line with a 'new imperialist' vision of industrial and technological modernity". " "Transformative occupation" has proven to be a fruitful and still much to be explored concept with which to analyse how interwar Mandates, in what was beginning to be labelled as the "Middle East", led to profound changes and tensions with repercussions until this day. ${ }^{2}$ The emphasis has been on the economic and political impact of capitalist modernisation and forceful colonial administration, highlighting the frictions between the Wilsonian ideal of national self-determination for all peoples and exertions of Western imperial control that supposedly paved the way to sovereignty. Greater attention needs to be paid to the transformative effect of cultural and linguistic strategies with which the British as well as other European powers influenced the self-perception and cultural

\footnotetext{
${ }^{1}$ Jacob Norris, "Transforming the Holy Land: The Ideology of Development and the British Mandate in Palestine," Humanity: An International Journal of Human Rights, Humanitarianism, and Development 8, no. 2 (Summer 2017): 280.

${ }^{2}$ Simon Jackson and A. Dirk Moses, "Transformative Occupations in the Modern Middle East," Humanity: An International Journal of Human Rights, Humanitarianism, and Development 8, no. 2 (Summer 2017): 232.
}

T. van Kessel $(\bowtie)$

University of Amsterdam, Amsterdam, The Netherlands

e-mail: T.M.C.vanKessel@uva.nl

(C) The Author(s) 2021

K. Sanchez Summerer and S. Zananiri (eds.), European Cultural

Diplomacy and Arab Christians in Palestine, 1918-1948,

https://doi.org/10.1007/978-3-030-55540-5_20 
identification of communities in Palestine during the Mandate period and were in turn affected by their experiences there.

Examining the cultural transformations that the Palestinian Christians underwent and brought about during the Mandate period can serve as effective starting point in gaining an understanding of these interwoven histories. The Palestinian Christians were generally more urbanised and hence exposed to European influences. Writing about Mandate Haifa, a city that was designated and developed by the British as gate to the Middle East Maayan Hilel in her contribution to this volume underscores that the Christiansand Melkites in particular-were the most likely to be employed in administration and private business under British rule. These were also the groups already most exposed to European influences through the educational activities of especially French Roman Catholic missionaries, whose schools were appealing to Maronites and even Greek Orthodox groups. Sarah Irving too confirms that Christian communities often had the most contact with Europeans and their educational, economic and administrative initiatives: an exposure to European modes of thinking which ironically meant that they were often the ones to be employed for the process of inventorising and protecting Palestinian cultural heritage that changes in lifestyle induced by Western influences were rendering obsolete and hence at risk of loss. ${ }^{3}$ Intermeshed with this was a culturalisation of political tensions brought about by the British Mandate government's attempts to treat all communities with equanimity and thus grant each their own cultural expressions. This in fact essentialised the religious identity of these communities. Furthermore, in a situation in which the British administration was accentuating and reconfiguring categories of race, ethnicity and religion, Christians in Palestine defied the simplified image of the Muslim Arab.

Cultural diplomacy suggests dialogue, whereas in the case of European cultural policies in Mandate Palestine and the response of local Christian communities, we are in fact often looking at one-way cultural projection and not always exchange. If there was exchange, this did not always convey the meanings or obtain the goals intended. The workings of such cultural crossroads, where encounters do or at times do not take place, require consistent attention to the multidirectionality of processes and purposes. As Dueck has observed in relation to Syria and Lebanon: "Culture was a political tool only when it buttressed the cultural or political aspirations of the local leadership and population". ${ }^{4}$ In other words, we need to be aware of the process of appropriation and subversion of European cultural activities to own ends that has taken place. In terms of viewing Mandatory Palestine as a case of transformative occupation, an important question is also whether the various European actors were themselves transformed by the local realities that they

\footnotetext{
${ }^{3}$ Sarah Irving in this volume.

${ }^{4}$ Jennifer Dueck, The Claims of Culture at Empire's End. Syria and Lebanon Under French Rule (Oxford: Oxford University Press, 2010), 229.
} 
were facing, including the confrontation with Christian cultures that did not sit comfortably with own conceptions of civilisational progress. ${ }^{5}$

In this volume we have seen instances of cultural models that were not absorbed in a straight-forward or foreseeable manner. For example, American humanitarian groups, non-denominational educational institutions such as the American University in Beirut, the Mission laïque française and European communist newspapers such as L'Humanité, were according to Idir Ouahes the largely unintended training grounds for Palestinian Christians to develop secular, anti-imperialist ideas and self-images. This is reminiscent of how introducing the Boy Scouts movement backfired: the British Mandate government grossly underestimated to what extent this form of activity could be absorbed by the local communities and put to use for their own political ends. In fact, the Palestinian Arab Scouts became "a subversive nightmare" and were to play an active role in the 1936-1939 Arab revolt. ${ }^{6}$ There seems at times to have been a blind eye for the resistance that certain European practices elicited. Despite the administration's striving to appear impartial at all times, all cultural interventions by the British could, if only because of their extraneous nature, be perceived as political. A case in point is the prevention of cruelty to animals. Seen by the British as part of the universal "civilising" humanitarianism that British interwar imperial identity stood for, it was embraced by some but also repudiated by a large part of the population in the Mandate as a malignant foreign imposition, especially in rural areas. $^{7}$

Writing about cultural diplomacy in the twenty-first century, Ien Ang, Yudhishthir Raj Isar and Phillip Mar have pointed out that there is a distinction to be made between cultural relations, that are the result of private initiative, and cultural diplomacy, which is by definition the work of diplomats promoting the interests of their respective governments. In recent years, scholars and practitioners have tended to blur these lines. ${ }^{8}$ In the period of the British Mandate, European governments-responding to the growing importance of public opinion and the emerging power of mass media-were only just beginning to properly develop their direct use of culture as a strategic tool, following the private initiatives developed in this field at the end of the nineteenth century. ${ }^{9}$ Here, the distinction between cultural relations and

\footnotetext{
${ }^{5}$ Jackson, "Transformative Occupations," 235.

${ }^{6}$ Arnon Degani, "They Were Prepared: The Palestinian Arab Scout Movement 1920-1948," British Journal of Middle Eastern Studies 41, no. 2 (2014): 201 and 205.

${ }^{7}$ Alma Igra, "Mandate Compassion: Prevention of Cruelty to Animals," The Journal of Imperial and Commonwealth History 47, no. 4 (2019): 773-799.

${ }^{8}$ Ien Ang, Yudhishthir Raj Isar, and Phillip Mar, "Cultural Diplomacy: Beyond the National Interest?" International Journal of Cultural Policy 21, no. 4 (2015): 365-381.

${ }^{9}$ Tamara van Kessel, Foreign Cultural Policy in the Interbellum: The Italian Dante Alighieri Society and the British Council Contesting the Mediterranean (Amsterdam: Amsterdam University Press, 2016).
} 
diplomacy was at times also blurred: in this case, unlike today, not because non-governmental players were gaining influence but, on the contrary, because governments were taking on more responsibility and agency in the instrumental use of culture rather than being indirectly involved. Adding to the blurring of lines is the specific role of religious institutions, which were to a lesser or greater extent tied to the national interests of European states, including Russia until the Bolshevik Revolution. The local communities in Palestine were themselves seeking appropriate forms of representation and cultural leadership, be it within the existing hierarchy of religious structures (such as in the Greek Orthodox Church) or in new types of cultural spokespeople, such as the organisers of the First National Arab Fair.

If we approach the cultural activities analysed in this volume as falling under the intersection between cultural diplomacy and cultural relations, then David Clarke's reflections on how Cultural Studies theory can elucidate the workings of cultural diplomacy become very relevant. ${ }^{10}$ Cultural Studies researchers take as a premise that every cultural product is "the site of struggle over meaning" and consequently that "consumption itself becomes a form of production". ${ }^{11}$ Clarke hence identifies four major actors involved in cultural diplomacy: policymakers, agents, cultural practitioners and consumers, whereby the relation between producers and consumers needs to be viewed critically. Rather like Dueck, Clarke calls for an awareness of the consumer's own agency in determining the meaning-making process. However, while he observes that identity issues will affect how consumers interpret the cultural product, the question arises how in turn this identity is conditioned by producers.

In view of this ambiguous power relation between producer and consumer, an issue that underlies several of the volume's chapters and which needs to be critically reconsidered, is the present and past influence of a western discourse of "modernity". To what extent do historical interpretations risk being trapped in the long-standing false dichotomy between modernity and the Mediterranean? As Naor Ben-Yehoyada has argued: "In the battle between two notions of modernity - pluralistic cultural elitism or nationalism-the latter had the upper hand". ${ }^{12}$ The northern European model of modernity, characterised by state formation, capitalism, urbanisation, individualisation and above all nationalism, became the antithesis of the Mediterranean; it stood at odds with cosmopolitan port cities such as Alexandria, Beirut, Istanbul and Izmir/Smyrna, which were still flourishing at the turn of the twentieth century. Scholars themselves need to be wary of transposing a simplistic dichotomy

\footnotetext{
${ }^{10}$ David Clarke, "Theorising the Role of Cultural Products in Cultural Diplomacy from a Cultural Studies Perspective," International Journal of Cultural Policy 22, no. 2 (2016): 147-163.

${ }^{11}$ Ibidem, 152.

${ }^{12}$ Naor Ben-Yehoyada, "Mediterranean Modernity?" in A Companion to Mediterranean History, eds. Peregrine Horden and Sharon Kinoshita (Hoboken, NJ: Wiley Blackwell, 2014), 117.
} 
between tradition and modernity onto the Mediterranean. ${ }^{13}$ The "hybrid Euro-Oriental cities" of this area and their enterprising middle-class inhabitants have been all too easily relegated to the periphery, ignoring how this hybridity enabled them to negotiate their own position between their Ottoman heritage, the emerging pan-Arabist and pan-Islamic movements, the openness required by trade and the new models of living presented by European powers. ${ }^{14}$

Hence, when studying the interaction between European cultural policies and Palestinian Christian's cultural affiliations and identifications, we need to ask: how did Christian Palestine Arabs - as a strongly urbanised part of the population-relate to western notions of cultural modernisation? How does a scholar tackle attitudes towards modernity in what was in many respects a colonial context, whereby civilisational ideals of European powers were more or less consciously absorbed or rejected? These ideas of modernity not only triggered the striving for cultural recognition of (a constructed) Palestinian Arab tradition but also both problematised and stimulated the local communities' potential as cultural producers. The British administrators' continuous concern with civilisational progress and their tendency to assign European Jews the role of carriers of progress, meant they disregarded the economic development that had already begun in late Ottoman Palestine and rejected the active role that Arab merchant classes were willing to play in its continuation. ${ }^{15}$ Furthermore, a considerable flow of emigrants from Palestine and the broader region who had returned by the time of the Mandate, formed a class of nouveaux riches that was culturally influential and by no means unfamiliar with industrialism, capitalism and state bureaucratisation. ${ }^{16}$ The framing of local populations as "undeveloped" was possibly not only the effect of colonial policy but also of internal processes of cultural distinction, which might have affected the collective sense of self of the various groups within the Christian communities in different ways.

The issue of "modernisation" also relates to the linguistic, educational and religious policies in Palestine, that according to Karène Sanchez Summerer still require more thorough exploration. ${ }^{17}$ While the British administration was imposing English and Hebrew as official languages besides the predominant Arabic, European mission schools negotiated national interests and

\footnotetext{
${ }^{13}$ Ibidem, 113-114.

${ }^{14}$ Christopher A. Bayly and Leila Fawaz, "Introduction: The Connected World of Empires," in Modernity and Culture: From the Mediterranean to the Indian Ocean, eds. Leila Tarai Fawaz and Christopher A. Bayly (New York: Columbia University Press, 2002), 9.

${ }^{15}$ Norris, "Transforming," 282.

${ }^{16}$ May Seikaly, "Haifa at the Crossroads: An Outpost of the New World Order," in Modernity and Culture: From the Mediterranean to the Indian Ocean, eds. Leila Tarai Fawaz and Christopher A. Bayly (New York: Columbia University Press, 2002), 96-111; Jacob Norris, "Return Migration and the Rise of the Palestinian Nouveaux Riches, 1870-1925," Journal of Palestine Studies XLVI, no. 2 (Winter 2017): 60-75.

${ }^{17}$ Karène Sanchez Summerer, "Linguistic Diversity and Ideologies Among the Catholic Minority in Mandate Palestine. Fear of Confusion or a Powerful Tool?" British Journal of Middle Eastern Studies 43, no. 2 (2016): 191-205.
} 
religious universality, the latter being especially emphasised by the Roman Catholic Holy See. Applying diverse strategies, these schools continued to teach French, Italian and Russian respectively, and, depending on the religious order, taught mostly or partly in Arabic, seen as the most effective language in terms of catechism and proselytism. This exposure to European cultivation of the national language directly and indirectly gave an impulse to Palestinian Arab identification with the Arabic language. At the same time, English was becoming invariably associated with "modernisation" and the career prospects made possible by the British and their imperial network, not unlike French and Italian which from the mid-nineteenth century onwards had been embraced by local elites. ${ }^{18}$ In this context, the fact that Catholic Palestinians continued to cherish their habitual multilingualism did not go well with the logic of state formation and of monolingualism for each community which the British government applied to this Mandate. ${ }^{19}$

There are parallels to be drawn between how the British government tried to expel the use of Italian on Malta to counter Catholic and Italian Fascist influences, and promoted the Maltese vernacular on the grounds that children's cognitive development would be hampered if they were taught in more languages than their "mother tongue" ${ }^{20}$ The same pragmatism with which French schools in Palestine offered education in English and Arabic to give greater access to the job market, resurfaces in Italian schools in Malta that offered English to enable pupils to work for the British Navy or administration. ${ }^{21}$ European linguistic policies adapted to on the ground realities and comparing the strategies within Palestine and beyond can help to pinpoint what the underlying assumptions of these different governments and (religious) organisations were. Although Palestine was classified as a type A mandate, it is worth recalling what Hans-Georg Wolf has observed with regard to the differences that can be found in the linguistic divulgation by the French and the British governments in their type B mandates. The British did not encourage the use of English in these latter mandates: local populations were "forced into a colonial framework but were discouraged from aspiring to become like their colonial masters (...)" ${ }^{22}$ English as a language did not permeate the local elites as did French, nor did it become the lingua franca, something which Wolf explains as being the consequence of the British having a far more utilitarian and socio-racist approach to the territory and its population. As this volume has shown, similar ideological differences emerge

\footnotetext{
${ }^{18}$ Ibidem, 194 and 197-198.

${ }^{19}$ Ibidem, 193.

${ }^{20}$ Ibidem, 197; Van Kessel, Foreign Cultural Policy, 146.

${ }^{21}$ Sanchez Summerer, "Linguistic Diversity," 199-200; Van Kessel, Foreign Cultural Policy, 147.

${ }^{22}$ Hans-Georg Wolf, "British and French Language and Educational Policies in the Mandate and Trusteeship Territories," Language Sciences 30 (2008): 569, https://doi.org/10.1016/j. langsci.2007.07.002.
} 
in the European cultural and linguistic enterprises developed in Mandate Palestine. When focussing on the Christian Arabs, the targeting and the response vary also between the denominations within this category of citizens at which these policies were aimed, bringing to the fore also the religious allegiances that overlapped or clashed with national ones.

\section{BIBLIOGRAPHY}

Ang, Ien, Yudhishthir Raj Isar, and Phillip Mar. "Cultural Diplomacy: Beyond the National Interest?" International Journal of Cultural Policy 21, no. 4 (2015): 365-381.

Bayly, Christopher A., and Leila Fawaz. "Introduction: The Connected World of Empires." In Modernity and Culture: From the Mediterranean to the Indian Ocean, edited by Leila Tarai Fawaz and Christopher A. Bayly, 1-27. New York: Columbia University Press, 2002.

Ben-Yehoyada, Naor. Mediterranean Modernity? In A Companion to Mediterranean History, edited by Peregrine Horden and Sharon Kinoshita, 107-121. Hoboken, NJ: Wiley Blackwell, 2014.

Clarke, David. "Theorising the Role of Cultural Products in Cultural Diplomacy from a Cultural Studies Perspective." International Journal of Cultural Policy 22, no. 2 (2016): 147-163.

Degani, Arnon. "They Were Prepared: The Palestinian Arab Scout Movement 19201948." British Journal of Middle Eastern Studies 41, no. 2 (2014): 200-218.

Dueck, Jennifer. The Claims of Culture at Empire's End. Syria and Lebanon Under French Rule. Oxford: Oxford University Press, 2010.

Igra, Alma. "Mandate Compassion: Prevention of Cruelty to Animals." The Journal of Imperial and Commonwealth History 47, no. 4 (2019): 773-799.

Jackson, Simon, and A. Dirk Moses. "Transformative Occupations in the Modern Middle East." Humanity: An International Journal of Human Rights, Humanitarianism, and Development 8, no. 2 (Summer 2017): 232.

Kessel, Tamara van. Foreign Cultural Policy in the Interbellum: The Italian Dante Alighieri Society and the British Council Contesting the Mediterranean. Amsterdam: Amsterdam University Press, 2016.

Norris, Jacob. "Return Migration and the Rise of the Palestinian Nouveaux Riches, 1870-1925." Journal of Palestine Studies XLVI, no. 2 (Winter 2017): 60-75.

— . "Transforming the Holy Land: The Ideology of Development and the British Mandate in Palestine." Humanity: An International Journal of Human Rights, Humanitarianism, and Development 8, no. 2 (Summer 2017): 269-286.

Sanchez Summerer, Karène. "Linguistic Diversity and Ideologies Among the Catholic Minority in Mandate Palestine. Fear of Confusion or a Powerful Tool?” British Journal of Middle Eastern Studies 43, no. 2 (2016): 191-205.

Seikaly, May. "Haifa at the Crossroads: An Outpost of the New World Order." In Modernity and Culture: From the Mediterranean to the Indian Ocean, edited by Leila Tarai Fawaz and Christopher A. Bayly, 96-111. New York: Columbia University Press, 2002.

Wolf, Hans-Georg. "British and French Language and Educational Policies in the Mandate and Trusteeship Territories." Language Sciences 30 (2008): 553-574. https://doi.org/10.1016/j.langsci.2007.07.002. 
Open Access This chapter is licensed under the terms of the Creative Commons Attribution 4.0 International License (http://creativecommons.org/licenses/ by $/ 4.0 /)$, which permits use, sharing, adaptation, distribution and reproduction in any medium or format, as long as you give appropriate credit to the original author(s) and the source, provide a link to the Creative Commons license and indicate if changes were made.

The images or other third party material in this chapter are included in the chapter's Creative Commons license, unless indicated otherwise in a credit line to the material. If material is not included in the chapter's Creative Commons license and your intended use is not permitted by statutory regulation or exceeds the permitted use, you will need to obtain permission directly from the copyright holder. 